\title{
Post-Modern Relativist Challenges on Islamic Epistemology
}

\author{
Mohamed Safiullah Munsoor \\ Islamic Solidarity Fund for Development, MMunsoor@isdb.org
}

\begin{abstract}
With the emergence of the quantum world and the emerging weaknesses of the positivistic notion of science, post-modernism relativism emerged taking the world view that we constructed our own social reality. Thus, there are no such things as objectivity and truth. This amongst other things paved the way for secularism especially within the Western world, where its philosophy has been incorporated both in its education system and its multi-media, which has invariably impacted the Muslim world. The methodology entailed examining relevant Sociological text, as well as selected Islamic traditional literature including the creed of Taftanzanī, Al-Ghazālī, Ibn Hazm amongst others and inter-linking it with Qur'an and Prophetic hadiths. Post-modernism poses a challenge to Islam by way of trying to incorporate alternative narratives into its institutional structures. The solution to overcome this is by inculcating greater awareness amongst the Muslims, as well as properly understanding and disseminating the nature of knowledge of Islam in its multi-dimensional forms. Islam integrates the sacred and the profane, with accent on this world (dunya $)$ - next world (akhira). It is thus more holistic and profound, subsuming both the rational and non-rational elements, as well as giving life a definite meaning and direction.
\end{abstract}

Keywords: epistemology, ontology, post-modernism, Islam, knowledge, rational, non-rational

\section{Introduction}

Islam in the $14^{\text {th }}$ Century and its declining civilization can be characterized as causing a shift in paradigm, where one witnessed a "series of peaceful interludes punctuated by intellectually violent revolution", with "one conceptual world view is replaced by another" as a result of colonization.

A millennium after the emergence of Islam, one saw another paradigm shift occurring, with the emergence of the industrial revolution, which paved the way for modernization and other ways of thinking as against the traditional mind set. This as we have seen has had a major impact on society and its way of thinking as a whole especially in the Northern hemisphere, which has become synonyms with westernization. 
There are several questions that can be posed in the above context-what sort of impact did this cause in people's thinking and behaviour especially in terms of religion, which influenced the socio-cultural aspects of society? Do the theories and principles of modernism still hold or has this given way to a new way of thinking? What weaknesses have emerged from modernism? What impact has modernism and post-modernism had on Islam, its way of inquiry, thinking and on its body of knowledge?

This paper examines these above mentioned questions, while first defining the key terms. It has a closer look at postmodernisation and its way of thinking, which examining the fundamentals of modernization and Islamic Epistemology. This is then followed by outlining the challenges of post-modern relativism on Islamic epistemology, which is done through deciphering the works of some eminent traditional Islamic Scholars. Following this, an integrated discussion ensues and finally a conclusion is drawn from the resulting discussion.

\section{Key Definitions}

Ontology and epistemology are often paired together and sometimes confused warranting an explanation. Ontology is defined as a 'systematic account of existence' ${ }^{1}$, where it is concerned with nature of being with the kinds of being that have existence ${ }^{2}$.

Epistemology is more wider in scope dealing with 'the study of knowledge and justified belief" ${ }^{3}$ and poses a number of questions: How do we understand the concept of justification? (evidence vs. reliability, internal vs. external), what are the necessary and sufficient conditions of knowledge? What are its sources (perception, introspection, memory, reason, testimony)? What are its structure and what are its limits (foundationalism,

1 T.R. Gruber, What is Ontology, last modified 1992, http://wwwksl.stanford.edu/kst/what-is-an-ontology.html, accessed $5^{\text {th }}$ January 2014

2 Merriam Webster Dictionary; http://www.merriam-webster.com/dictionary /ontology, accessed on December 2013

3 Steup Matthias, "Epistemology", The Stanford Encyclopedia of Philosophy (Winter 2013 Edition), Edward N. Zalta (ed.), http://plato.stanford.edu /archives/win2013/entries/epistemology/, accessed $4^{\text {th }}$ December 2013. 
coherentism)? It focuses on creating and disseminating knowledge within specific areas of inquiry ${ }^{4}$.

Post-modernism, a late $20^{\text {th }}$ Century movement was a reaction generated to the positivistic-logical-objectivity perspective $\left(16^{\text {th }}\right.$ and $17^{\text {th }}$ Century), which included the so-called period of the $18^{\text {th }}$ Century enlightenment. It developed a critique of modernism including its scientific premises resulting in a change in the world view, where social and environmental realities are seen as human constructs. In this light, it is characterized by skepticism, subjectivism or relativism, which challenged reason and critiqued the role of ideology ${ }^{5}$. Its key perspectives are outlined in the section that follows.

\section{Fundamentals Elements of Post-Modernism}

For ease of review and reflection, the various points relating to Modernism and Post-Modernism are represented as in Table 1 below. The scientific revolution, which formed a basis for the industrial revolution, as well as the development of modern science and technology, was firmly rooted with its 'scientific paradigm', its objectivity and rigor of analysis and interpretation. As time evolved and with the advancement of science some fundamental theories were superseded, such as, the shift in the Newtonian to an Einsteinian Relativity perspective and a more recent a Quantum way of looking at the world. This triggered a paradigm shift, which affected the way in which we view the world. This also impacted society at large out of which was born post-modernism.

From the differentiation cited below in the Table 1, it can be seen that they are opposing world views, which cannot be reconciled given that post-modernism has resulted from the weakness that has arisen from modernism and its scientific premise. Post-modernism has its own weakness and this will be further elaborate in the section on discussion.

The positivist tradition, which characterizes the scientific revolution and modernism, subsumes both empiricism and

\footnotetext{
4 Steup, "Epistemology."

5 Brian Duigan, Postmodernism (philosophy), Britannica Online Encyclopedia, www.Britannica.com?EBchecked/topic/107729/postmodernism-andrelativisim, accessed on 21 November 2013, 1.
} 
realism. This forms the empiricist tradition ${ }^{6}$, where the core assumptions are that facts can be collected on the social world independent of how people would interpret them (See Table 1). The Post-Modernism ${ }^{7}$ framework outlines that there is no social world beyond people's perception and interpretation and it includes the naturalistic and interpretivistic tradition (See Table 1).

Table 1 - Modernism versus Post-Modernism ${ }^{8}$

\begin{tabular}{|c|c|}
\hline Modernism & Post-Modernism \\
\hline $\begin{array}{l}\text { 1. There is an objective } \\
\text { natural reality, whose } \\
\text { existence is independent of } \\
\text { human beings, their societies, } \\
\text { their social practices or their } \\
\text { investigation techniques. }\end{array}$ & $\begin{array}{l}\text { Reality is a social and } \\
\text { conceptual construct and an } \\
\text { artefact of scientific practice } \\
\text { and language. Thus, this } \\
\text { means that there is no } \\
\text { objective reality. }\end{array}$ \\
\hline $\begin{array}{l}\text { 2. The descriptive and } \\
\text { explanatory statements of } \\
\text { scientists and historians can, } \\
\text { in principle, be objectively } \\
\text { true or false. }\end{array}$ & $\begin{array}{l}\text { Based on the rejection of an } \\
\text { objective reality, this follows } \\
\text { on that there is no such thing } \\
\text { as truth. }\end{array}$ \\
\hline $\begin{array}{l}\text { 3. Human beings are able to } \\
\text { change themselves and their } \\
\text { societies for the better by their } \\
\text { use of science and } \\
\text { technology. Derived from } \\
\text { this, as societies evolve they } \\
\text { will become more humane, } \\
\text { just, prosperous and } \\
\text { enlightened. }\end{array}$ & $\begin{array}{l}\text { This is a misguided view, } \\
\text { where science and technology } \\
\text { in the hands of those who are } \\
\text { evil has led to oppression and } \\
\text { destruction. }\end{array}$ \\
\hline
\end{tabular}

6 Tim May, Issues, Methods and Processes (Open University Press, 1997), 1011 quoted in Mohamed Safiullah Munsoor, "A Qualitative Assessment of Successful Local Organisations (LOs): A Critical Study of Northern Rakhine State (NRS), Myanmar" (Ph.D thesis, University of Reading, UK, 2003), 95.

7 May, Issues, Methods and Processes, 10-11 quoted in Munsoor, "A Qualitative Assessment of Successful Local Organisations (LOs)," 95.

8 Duigan, Postmodernism (philosophy), 1-2. 


\begin{tabular}{|c|c|}
\hline $\begin{array}{l}\text { 4. Reason and logic are } \\
\text { universally valid, meaning } \\
\text { that their laws are the same } \\
\text { for any thinker and any } \\
\text { domain of knowledge. }\end{array}$ & $\begin{array}{l}\text { Both reason and logic by } \\
\text { virtue of them being } \\
\text { conceptual constructs are only } \\
\text { valid within their established } \\
\text { intellectual traditions in which } \\
\text { they are applied. }\end{array}$ \\
\hline $\begin{array}{l}\text { 5. There is a reality called } \\
\text { human nature, which consists } \\
\text { of faculties, aptitude, or } \\
\text { dispositions and they are } \\
\text { present in human beings at } \\
\text { birth. }\end{array}$ & $\begin{array}{l}\text { Nearly all aspects of human } \\
\text { psychology are learned } \\
\text { through social interaction or } \\
\text { forces and therefore are } \\
\text { socially determined. }\end{array}$ \\
\hline $\begin{array}{l}\text { 6. Language refers to and } \\
\text { represents a reality outside } \\
\text { itself. }\end{array}$ & $\begin{array}{l}\text { Language is semantically self- } \\
\text { contained or self-referential, } \\
\text { meaning that, natural } \\
\text { languages and discourses are } \\
\text { embedded within social } \\
\text { practices, where they are } \\
\text { determined by the moral and } \\
\text { intellectual values of the } \\
\text { particular community or } \\
\text { tradition. }\end{array}$ \\
\hline $\begin{array}{l}\text { 7. Human being can acquire } \\
\text { knowledge about natural } \\
\text { reality and this can be } \\
\text { justified based on evidence or } \\
\text { principles with certainty. }\end{array}$ & $\begin{array}{l}\text { There is no such reality, which } \\
\text { can be thus justified based on } \\
\text { evidence and with certainty. }\end{array}$ \\
\hline $\begin{array}{l}\text { 8. In principle, it is possible to } \\
\text { construct a general theories, } \\
\text { which can explain the natural } \\
\text { and the social worlds within a } \\
\text { given domain of knowledge, } \\
\text { e.g. general theory of human } \\
\text { history; dialectical } \\
\text { materialism. }\end{array}$ & $\begin{array}{l}\text { It is not possible to construct } \\
\text { general theories or meta- } \\
\text { narratives pertaining to human } \\
\text { biology, historical or social } \\
\text { development. These so-called } \\
\text { theories are false since they } \\
\text { impose conformity on their } \\
\text { perspective or discourses and } \\
\text { as such they over-ride or } \\
\text { marginalize them. }\end{array}$ \\
\hline
\end{tabular}


Language and its role in society play a vital part in postmodernistic thought, as captured in Table 1 . In this context, poststructuralis ${ }^{9}$ emphasizes that knowledge and power are constructed within a set of social practices. In Michel Foucault's ${ }^{10}$ way of thinking "who we are, what we think and what we know are created by the discourse available to us to use". This discourse acts as a medium through which knowledge and action are known and which in turns shapes behaviour.

Knowledge according to Foucault ${ }^{11}$ is utilized "to oppress, control and coerce". In this the light, social change is not categorized as progress but that which is centered around creation of different discourses resulting in varying types of oppression control and coercion. The concept of power says Foucault ${ }^{12}$ comes into being in two ways, first, "it is exercised so that a discourse is enabled to come into being" and by the discourse itself, "it controls the ways of thinking, knowing and actions of those individuals who use it".

Habermas ${ }^{13}$, who developed the critical theory approach, which forms a part of post-modernism, provides a compound definition of knowledge as being 'knowledge-constitutiveinterest', where various vested interests tends to shape a multitude of activities. He thus argues that knowledge is not a purely intellectual act but it is moulded by those pursuing it $^{14}$. It is thus important states Carr and Kemmis ${ }^{15}$ that one needs to look beyond

9 Derrida and Foucault in Tim May, Issues, Methods and Processes (Philadelphia: Open University Press, 1997), quoted in Munsoor, "A Qualitative Assessment of Successful Local Organisations (LOs)," 98.

${ }^{10}$ Thompson et al., 252 quoted in Munsoor, "A Qualitative Assessment of Successful Local Organisations (LOs),, 98.

${ }^{11}$ Thompson et al., 252 quoted in Munsoor, "A Qualitative Assessment of Successful Local Organisations (LOs),, 253.

12 Thompson et al., 252 quoted in Munsoor, "A Qualitative Assessment of Successful Local Organisations (LOs)," 253.

13 J. Habermas in Wilfred Carr and Stephen Kemmis, Becoming Critical: Education, Knowledge and Action Research (The Falmer Press, London, 1986), 134, quoted in Munsoor, "A Qualitative Assessment of Successful Local Organisations (LOs),, 98.

${ }^{14}$ Habermas, Becoming Critical, 134, quoted in Munsoor, "A Qualitative Assessment of Successful Local Organisations (LOs)," 135-136.

${ }^{15}$ Habermas, Becoming Critical, 134, quoted in Munsoor, "A Qualitative Assessment of Successful Local Organisations (LOs)," 137. 
the interpretative approach, with the 'uncritical rendering of individuals' self-understanding', since this is shaped says Habermas by the socio-political conditions. From this above rendering of social and environmentally deterministic postmodernist view point, we now turn to examine the Islamic perspective on it.

\section{Fundamental Elements of Islamic Epistemology}

The frequency with which 'Ilm or knowledge, which occurs in the Qur'an and its emphasis by the Prophet (saw), forged a firm foundation on which Islamic epistemology was developed by several Islamic thinkers notably Ibn Sina, al-Farabi, Ibn Rushd, Ibn Bajja, Ibn Rushd, Al-Ghazali amongst several others. Islam includes several perspectives and is thus not monolithic as reflected in Table 2 .

There were many notable scholars including Imam alHaramayn (478/1083), al-Ghazālī (450/1058), al-Qanāwī (672/1273); who stated that knowledge was too complicated a concept to simply state it and can be defined through disjuncture (qisma) or example (mithal), while Fakhr al-Din al-Rāzi's (606/1209) point was that 'the knowledge of knowledge either must be intuitive (badihi) or necessary (darūrī), if not it will be tautological $^{16}$. Ibn al-Arabī (543/1148), on the other hand, thought that knowledge did not need any explanation since it was too clear a concept ${ }^{17}$. In spite of this, it can be stated as being that "most of the definitions are based on the assumption that the explanation of a subjective mental (psychological) process in its relationship to the objective, the mastery of concrete data, somehow suffices to grasp the nature of knowledge ${ }^{18}$.

It is evident from the Table 3, that there is much variation in how knowledge is generated, categorized and disseminated, which forms the basis of the Islamic ${ }^{19}$ epistemology. It ranges from the use of the senses to the use of the rational faculties including reason, as well as true narratives that is not a part either of the

\footnotetext{
${ }^{16}$ Franz Rosenthal, Knowledge Triumphant: The Concept of Knowledge in Medieval Islam (Leiden: Brill, 2007), 48-50.

${ }^{17}$ Rosenthal, Knowledge Triumphant, 50.

${ }^{18}$ Rosenthal, Knowledge Triumphant, 51.

${ }^{19}$ Rosenthal, Knowledge Triumphant, 19.
} 
senses or the rational facultative process but by direct descent of divine knowledge to the Prophets, which is a distinguishing point between Islam and post-modernism.

Knowledge and its generation and dissemination is firmly embedded in the Qur'an and the Prophetic tradition in a very significant manner that Rosenthal states that "Muhammad's concept of 'knowledge' set intellectual life in Islam on its basically unchangeable course" and "The triumphs and defeats of Muslim civilization are foreshadowed in Muhammad's understanding of knowledge"20.

Table 2 - Definitions of Knowledge ${ }^{21}$

\begin{tabular}{|c|c|}
\hline Definition & Source \\
\hline $\begin{array}{l}\text { Knowledge is that through } \\
\text { which one knows }\end{array}$ & $\begin{array}{l}\text { Al-Ghazali, Mustasfa, 1:16; } \\
\text { al-Amidi, Abkar (derived from } \\
\text { Abu 'l-Qasim al-Isfara'ini) }\end{array}$ \\
\hline $\begin{array}{l}\text { Knowledge is that through } \\
\text { which the essence is knowing }\end{array}$ & $\begin{array}{l}\text { Al-Ghazzali, Mustasfa, 1:16; } \\
\text { al-Sabuni, Kifayah (as the } \\
\text { definition of al-Ash'ari) }\end{array}$ \\
\hline $\begin{array}{l}\text { Knowledge is that through } \\
\text { which the object known (al- } \\
\text { ma lum) is known }\end{array}$ & Imam al-Haramayn, Luma, 88 \\
\hline $\begin{array}{l}\text { Knowledge is that through } \\
\text { which the knower knows the } \\
\text { object }\end{array}$ & $\begin{array}{l}\text { Quoted as } \\
\text { definition in Ms. Koprulu I, } \\
856\end{array}$ \\
\hline $\begin{array}{l}\text { Knowledge is that through } \\
\text { which the knower is knowing }\end{array}$ & $\begin{array}{l}\text { The Istanbul Manuscript Aya } \\
\text { Sofya 2378, folio. 21a } \\
\text { (authorship remains to be } \\
\text { determined), with the } \\
\text { manuscript being dated } \\
790 / 1388\end{array}$ \\
\hline $\begin{array}{l}\text { Knowledge is that which } \\
\text { necessitates for him in whom } \\
\text { it subsists the name of knower }\end{array}$ & $\begin{array}{l}\text { Al-Amidi, Abkar, folio 2b, } \\
\text { where al-Ash'ari is indicated } \\
\text { as the author of this definition }\end{array}$ \\
\hline
\end{tabular}

${ }^{20}$ Rosenthal, Knowledge Triumphant, 32.

${ }^{21}$ Rosenthal, Knowledge Triumphant, 52. 


\begin{tabular}{|c|c|}
\hline $\begin{array}{l}\text { Knowledge is that which } \\
\text { necessitates that he in whom it } \\
\text { subsists is knowing }\end{array}$ & $\begin{array}{l}\text { This definition is ascribed to } \\
\text { al-Ash'ari; cited in al-Amidi, } \\
\text { Abkar, folio 2b; al-Iji, } \\
\text { Mawaqif; al-Tahanawi, } 1058\end{array}$ \\
\hline $\begin{array}{l}\text { Knowledge is that which } \\
\text { necessitates that he in whom it } \\
\text { resides (mahall) is knowing }\end{array}$ & $\begin{array}{l}\text { Imam al-Haramayn, Irshad (as } \\
\text { the definition of our Shaykh, } \\
\text { apparently al-Ash'ari); Ibn } \\
\text { Sab'in, Budd, } 3\end{array}$ \\
\hline $\begin{array}{l}\text { Knowledge stands for the } \\
\text { object known }\end{array}$ & $\begin{array}{l}\text { Ibn Qayyim al-Jawziyah, } \\
\text { Bada'i al-Fawa'id, 2:91; al- } \\
\text { Ghazzali, Maqasid, 2:73 }\end{array}$ \\
\hline $\begin{array}{l}\text { Knowledge is but the concepts } \\
\text { known (al-ma'ana al- } \\
\text { ma'lumah) }\end{array}$ & $\begin{array}{l}\text { In kitab as-Sa'adah, 58, cited } \\
\text { as the definition of Themistius }\end{array}$ \\
\hline $\begin{array}{l}\text { Knowledge is the mentally } \\
\text { existing object (al-mawjud al- } \\
\text { dhihni) }\end{array}$ & $\begin{array}{l}\text { Al-Tahanawi, 1061-1062, } \\
1: 27 \text {, as a definition of the } \\
\text { philosophers, al-Iji, Mawaqif }\end{array}$ \\
\hline $\begin{array}{l}\text { Knowledge is the attribute } \\
\text { through which the knower } \\
\text { knows }\end{array}$ & Ibn Sab'in, Budd, 15 \\
\hline $\begin{array}{l}\text { Knowledge is an attribute } \\
\text { through which he who is alive } \\
\text { becomes knowing }\end{array}$ & Abd al-Qahir, Usul, 5 \\
\hline $\begin{array}{l}\text { Knowing is an attribute } \\
\text { expressing the relationship } \\
\text { (sifah 'udifah) between the } \\
\text { knower and the object known }\end{array}$ & \\
\hline $\begin{array}{l}\text { Knowledge is an attribute } \\
\text { through which the conditions } \\
\text { of the object known become } \\
\text { clear as they are ('ala ma } \\
\text { huwa alayh min ahwalih) }\end{array}$ & \\
\hline Knowledge is cognition & \\
\hline $\begin{array}{l}\text { Knowledge is the cognition of } \\
\text { the object know as it is ('ala } \\
\text { ma huwa bih) }\end{array}$ & $\begin{array}{l}\text { This definition was adopted by } \\
\text { al-Baqillani }\end{array}$ \\
\hline
\end{tabular}

From Table 3, it is evident that both the rationalistic knowledge including the use of the intellect and reason; as well as 
the non-rationalistic knowledge, which includes Prophetic revelation, intuition, illumination are subsumed within the framework of Islamic Epistemology. As al-Ghazāli ${ }^{22}$ points out that there is no conflict of Islam with the scientific or the rational traditions and it is to be noted that they have their respective 'sharia' or body of knowledge, where a person who opposes it has not fully understood their respective positions.

Table 3 - Islamic Perspective on Facets of Knowledge and their Meanings

\begin{tabular}{|l|l|}
\hline \multicolumn{1}{|c|}{$\begin{array}{l}\text { Facets of } \\
\text { Knowledge }\end{array}$} & \multicolumn{1}{c|}{ Explanation-Meanings } \\
\hline $\begin{array}{l}\text { Nature of } \\
\text { knowledge } \\
23\end{array}$ & $\begin{array}{l}\text { The grasping of the immaterial forms, natures, } \\
\text { essences or realities of things. Knowledge in the } \\
\text { human mind consists of conception (taşawwūr) } \\
\text { and assent (taşdiq). The former being } \\
\text { apprehension of an object with no judgment, and } \\
\text { the latter is apprehension with judgment - the } \\
\text { philosophical way. }\end{array}$ \\
\hline $\begin{array}{l}\text { Sources of } \\
\text { knowledge }\end{array}$ & $\begin{array}{l}\text { There are two theories of reducing unknown } \\
\text { objects, namely, Know to unknown objects } \\
\text { affected through an explanation (al-qawl al- } \\
\text { sarih) and the proof (al-burhän). It can be valid } \\
\text { or invalid. Secondly, through direct illumination } \\
\text { through the divine world - the Prophetic way. }\end{array}$ \\
\hline $\begin{array}{l}\text { Causes of } \\
\text { knowledge } \\
25\end{array}$ & $\begin{array}{l}\text { The sound senses, true narrative and reason The } \\
\text { senses are five including hearing, seeing, smelling, } \\
\text { taste and touch. True narrative is of two kinds: } \\
\text { those established by the tongue of the people over } \\
\text { time (mutawwatir), and the Prophetic narrative by } \\
\text { an evidentiary miracle. Reason includes discerning } \\
\text { knowledge and deductive reasoning. }\end{array}$ \\
\hline
\end{tabular}

${ }^{22}$ Rosenthal, Knowledge Triumphant, 21.

${ }^{23}$ Shams Inati, "Epistemology in Islamic Philosophy", 1998, 2-3; http//muslim philosophy.com/ip/rep/HO19; accessed on $2^{\text {nd }}$ December 2013.

${ }^{24}$ Inati, "Epistemology in Islamic Philosophy".

${ }^{25}$ Sa'd al-Din al-Taftazani, On the Creed of Najm al-Din al-Nasafi: A Commentary on the Creed of Islam, translated with introduction and notes by Earl Adgar Elder, edited by Austin P. Evans (Columbia University Press, New York, 1950), 15. 


\begin{tabular}{|l|l|}
\hline $\begin{array}{l}\text { Logic and } \\
\text { knowledge }\end{array}$ & $\begin{array}{l}\text { Deal with realities that exit in the mind and as } \\
\text { exemplified by subject or predicate, universality } \\
\text { or particularity, potentiality or accidentally. }\end{array}$ \\
\hline $\begin{array}{l}\text { Role of the } \\
\text { Mind }^{27}\end{array}$ & $\begin{array}{l}\text { Apart from the senses, the mind in this context is } \\
\text { equated with the 'rational soul', which has the } \\
\text { practical intellect and the theoretical intellect. } \\
\text { The former is responsible for proper management } \\
\text { of the body via apprehension of particular things } \\
\text { so as to do goodness and deflect evil, while the } \\
\text { latter is responsible for knowledge. }\end{array}$ \\
\hline $\begin{array}{l}\text { Philosophic } \\
\text { al-Prophetic } \\
\text { Knowledge } \\
28\end{array}$ & $\begin{array}{l}\text { The philosophical way is the movement from } \\
\text { imagination to the theoretical intellect (assent), } \\
\text { while the Prophetic way is the reverse, where it } \\
\text { moves from the theoretical intellect to the } \\
\text { imagination (decent). }\end{array}$ \\
\hline
\end{tabular}

\section{The Challenges of Post-Modernistic Relativisms to Islamic Epistemology}

The Khunian paradigm shift has been evident historically 'with violent intellectual revolutions' occurring from time to time in history, where Islam, a divine providence championed by Prophet (saw), chartered a course that resulted in a civilisation that shaped both the intellectual and spiritual life of societies. A millennium after this, another intellectual explosion occurred causing a paradigm shifts, first, with the emergence of modern science, with its period of so-called enlightenment, where religion, which was not liable for rigorous scientific scrutiny was gradually discarded. This impacted society and its values, where people were bound to explain phenomena according to science, which is underlined by reason and logic.

With the course of time and further advancement of science and society, there crept in disenchantment with the instrumentation of science and its world view out of which postmodernism was born. It can be said that post-modernism is largely socially and environmentally deterministic, meaning that, the human psychology including the thought process and the world

\footnotetext{
${ }^{26}$ Inati, "Epistemology in Islamic Philosophy."

${ }^{27}$ Inati, "Epistemology in Islamic Philosophy."

${ }^{28}$ Inati, "Epistemology in Islamic Philosophy."
} 
views created by humans are embedded, within the social practices and the language and its ensuing discourse formulated by the various segments of society. These discourses as conceived by Foucault played a vital role in how we think, create meaning and play out action in this world. The self, which creates knowledge is shaped by the prevailing discourse, as well as the socio-political conditions as Habermas perceived it. These above outlined aspects constituted some of the main elements of post-modernism.

The system of our current education system, which produces much of the world's intellectuals are shaped by modernistic and post-modernistic thinking. While modernism has largely influenced the world and how we function materially, the postmodernism has laid the basis for secularization to take root, especially in the Western world, which invariably influences the other parts by virtue of their politico-economical dominance. In post-modernism, there is no objective reality out there, as well as there is no truth, which is seen as an individual and societal construct. Thus, in effect, there is no God or Supreme Intelligence, as well as there is no next life. Therefore, there is no place for religion in society and all of its teachings and symbols should effectively be discarded.

In post-modernism, all aspects are enshrined in material life, with the individuals or its collective self-interpretations and reflections being the most crucial aspects. Thus, there is no divine laws, no moral compass, which has been passed down by the Prophets and we humans are to construct our own life pathways and processes. In this way, the State and Religion has been dislocated, where religion was been discarded altogether from the educational and institutional systems, which is seen as being sophisticated and modern or post-modern going beyond traditions and their norms. By virtue of their increasing dominance of the West on the rest of the world, with its post-modernist framework within which secularism is embedded has impacted on individuals, whatever their religious faiths may be.

Islam in one sense has things in common with modernism as defined and generated by the scientific revolution, with such elements as understanding the causes of knowledge through sense perceptions and theoretical and practical intellect as espoused by Ibn Sina and expanded by Imam Ghazali. Islam's intellectual 
legacy, which saw advancements in many spheres of society science, technology and sociology, was the result of knowledge being at the centre of religion and their way of life.

While factoring in the sense experiences and the intellect, Islam firmly subsumes the non-rational instrument, the divine knowledge which was channeled through the Prophets. In this light, Islam presents a holistic framework in terms of its epistemology, as compared to both modernism and postmodernism, which is devoid of spiritual and the purpose of life. Islam is at greater variance with post-modernism in a sense, since the framework of the latter is largely based on human capacities and understanding, which is limited in itself. Ibn Hazm points out that "Intelligence has its limits it is useless unless it is based on the guidance of religion or on good fortune in this world".

Al-Attas points out that within the Islamic perspective, world view is not conceptualized as being generated by the senses and the intellect as in the Western sciences but that which is rooted within our current material existence - the dunya but also to what is beyond - the akira or the next world, to which the soul travels once material existence ceases. In this sense, the world view is rooted in the continuum of 'dunya-akira', where what you do in this world affects your abode in the next world.

World view in the Islamic sense represents 'vision of reality and truth' based on the divine framework, which does not change in space and time. There is no separation of the sacred and the profane rather it is integrated as one entity, which is different from the Western conception of things. In this light, it goes beyond the comprehension of sense experiences, to experiences, which are inter-linked with other dimensions, which are not of this world but that which is beyond.

Al-Attas argues that materialistic ideology including postmodernism, which evolved its ideological with its own philosophical system while Islam, on the other hand, arose from the Source itself needing no need to develop and mature given its divine nature. Thus in this sense, it can be argued that it is not a new religion but its essence has been in existence from the inception of human existence. What Prophet Muhammad brought forth is further interpretation and elaboration and the finality of the message. Thus, the Prophetic model flows from revelation and not 
shaped by culture as is world knowledge and cultural practices and nuances, that has crept into Islam.

This above statement of al-Attas is factual in distinguishing between westernisation and Islam, while drawing out that the nonrational or divine intervention points, out to its comparative differences. It can, however, be debated especially in the context of the theistic faiths, namely, Judaism and Christianity, which has emanated from divine intervention and believes in a next life, even though the teachings may have been changed over the course of time, still forms a large part of the faith of those in the West and does offer a moral compass for those who believe in a higher power. In all cases. however, one needs to differentiate what is religious and what derives from a cultural basis, which in a modern context poses a real issue given the cultural practices that has crept into religion and confused some of the masses.

The Islamic world view in seen within a framework that takes the shape of a continuum subsuming the opposing poles, example, the empirical-rational; inductive-deductive, subjective-objective, which al-Attas defines as the "Tawhid method of knowledge'.

Al-Attas argues that the Islamic worldview is rooted within the divine framework as encapsulated in the Qur'an and this is what should hold on to the and not be influenced by Aristotelian, Platonic or Hellenistic philosophies and its linked traditions. He explains the concept of nature of God as articulated in the Qur'an, with his numerous attributes. Even though God is able to create things, which are finite, $\mathrm{He}$ is distinct from it Himself and everything and every substance, with no end or beginning. He is transcendence and yet immanent but not in the sense of pantheistic paradigm. These qualities that apply to humans, which forms a part of the continuum, example, good-bad, happy-sad does not apply to Him, for $\mathrm{He}$ is beyond this limiting framework.

A counter argument can be presented in relation to the above articulation of Al-Attas as outlined above, where Islam being a universal faith does subsume some of the principles or fundamentals of Aristotelian, Platonic or Hellenistic philosophies and its linked traditions. This is best represented in the works of Al-Ghazali, Ibn Farabi, Ibn Rushd, Ibn Sina, Ibn al-Arabi and other eminent scholars both from a point of articulation of its content, as well as its critique. 
Al-Attas points out that knowledge can be derived from cognitive faculties (reason, scientific investigation), as well as non-cognitive means (intuition, internal senses and faculties, religious nature). This contrasts with the sociological positivist notion (modernism) that there is only as objective reality out there and this can be determined by using scientific methods and also disagrees with the phenomenological and constructivist method (post-modernism), where we construct our own reality. He points out to the soul not as a 'tabula rasa' but only bring a recipient of knowledge but also being as an active organ seeking to make sense and arrive at meanings. This reference by al-Attas to the soul emanates from the seminal works of Ibn Sina and Imam Ghazali relating to the rational soul, where its raison d'etre (the reason of being) is to unravel knowledge and concurrently seek knowledge to enlighten itself.

Al-Attas states that knowledge can be subjected to corruption resulting from the influence of science, philosophy and western ideology, which has led to change in the key concepts and terms or the lens that we tend to look through, which we try to understand various aspects of life. This is akin to Habermas's point that selfrepresentation of knowledge can be influenced by socio-political environment and thus be tainted. This above cited influence alAttas says, leads to cultural and moral dislocation resulting in the degeneration of the religious knowledge, faith and values. This he says is perpetuating the secular system and this is internalized through the educational system.

A pertinent discussion in the context of the above is that of the influence of human agency or structure. Thus, the question in this regard, is changes and influences are caused by human individuals or by the prevailing structures including institutions and societies. The answer may lie in context and evolution of how things are perceived and the inter-play of both human agency, as well as structure.

The above in-effect poses the most significant challenge to Islam since both children and adults are subject to these postmodern influences, which are either consciously or subconsciously internalized, which then can becomes a part of their psyche. Part of the solution to the challenge lies with the Muslims themselves and their societies, by properly studying and 
understanding their religion well enough and noting that Islam is holistic in its way of life and meanings as well as symbols permeates the whole of one's life including worship, interaction and dealing with others be it Muslims or non-Muslims. In this sense, Muslims often do not do justice to Islam, where theology, jurisprudence, worship and practice are at variance and one does not practice what one preaches.

Islam in this sense has been compartmentalized and ritualized, where knowledge has in certain segments of society become narrow and stagnant in contrast to the hallmarks of teachings of the Qur'an and the way of the Prophet (saw). Once this dislocation occurs, then ones faith and religion is weakened and people are only Muslim by name and not by their deeds, then this can be subjected to undue external influences portraying Islam as something, which it is not.

In this light, concept of education is elucidated by al-Attas, where it is equated with knowledge, which is driven by a moral compass and that when activated is manifested in the concerned persons having proper mannerism or 'adab' defined as right action. This can be taken further to mean right speech, right attitude, right intention, as resonated in the four noble truths is Buddhism $^{29}$. This frame of reference to right intention and action provides guiding principles to conduct oneself in the best of the moulds as did the Prophet (saw), as well as interact with others in an amicable manner. As often cited Prophetic statement "the best of you is the best in conduct" ${ }^{\prime 30}$.

The connection between knowledge and meaning is underlined by al-Attas, where the former includes both being educated, as well as having the right mannerism, while the latter is defined as a proper understanding of a place of a certain element within the component parts of the system within which it operates. He uses the nexus between knowledge-meaning and its positioning to create a framework, where things are ordered in a certain way, a

29 The Dalai Lama, The Four Noble Truths of Buddhism: Fundamentals of the Buddhist Teachings, translated by Geshe Thupten Jinps, edited by Dominique Side (Harper Collin Publishers, new Delhi, 1997), 34-41.

${ }^{30}$ Bukhari,; "Dealing with People and Good Character (al-Adab al-Mufrad alBukhari)," translated by Aisha Bewley, Sunni Path: On-Line Islamic Academy, http://www.sunnipath.com/library/Hadith/H0003P0014.aspx, accessed on $7^{\text {th }}$ January 2014. 
kind of a hierarchy, where there is a sense of harmony for this given it the right perspective.

The above is put into an Islamic perspective, where al-Attas says is derived from the criteria found in the Qur'an relating to knowledge, intelligence and virtue rather than from a human criteria of knowledge from wealth, lineage and power as articulated in the post-modernistic discourse. Knowledge and being, he says are expressed at different levels and degrees, and then attitude and behaviour are informed by actions, which the mind recognizes as being in conformity with the proper positioning of self. However, when the mind does not recognize the different degrees and levels disrupting the order in the legitimate hierarchy, then corruption sets in, when the mind in prone to social injustice, whereby the notion of the proper place does not exists both internally and externally resulting in the disintegration of adab or proper conduct.

An argument that can be drawn against al-Attas's above exposition is that even when one's interpretation is by the Qur'an, which is the divine revelation, there are divergences in both understanding and interpretation within the scared text, which ineffect has led to the emergence of divergent worldviews. This can be seen in the emergence of various groups, whose framework is based on violence and who use this to justify the killing of humans which includes the destruction of Muslims, Non-Muslims, women, children and elderly even though the Qur'an states that “...if anyone slays a human being unless it be (in punishment) for murder or for spreading corruption on earth - it shall be as though he had slain all mankind; whereas, if anyone saves a life, it shall be as though he had saved the lives of all mankind"31. Thus, here we see that the attitude, action and behaviour are different to the divine text.

In this sense apart from threat of post-modernism, the misinterpretation of the divine writ in Islam out of its content, context and framework by the Muslims themselves poses an internal threat that needs to be tackled systematically. This is manifested in especially the violent and intolerant movements both in the past as in the current context that advocates violence, intolerance and sectarianism in contrast to the Qur'anic

${ }^{31}$ Al-Qur'an, al-Ma'idah, 5:32. 
articulation "...that we are created as nations and tribes so that you can get to know each other". Leaders and Movements seems to advocated ideologies that are in line with their own self-interest, political agenda and sectarian ideologies. The non-monolithic nature of Islam and its divergent practices are best represented by the four Imam's, who were both conversant in the Qur' an and the Prophetic tradition, while being the closet in time to the Shahabas or the disciples of the Prophet and who lived during the first and second generations after the Prophet.

The essence here is to fully submit to God to elicit His divine guidance, while acquiring the right understanding of Islam as a universal faith not bound by a narrow brand of Islam, as well as by social and cultural parameters, which in-effect should forms the core definition of a Muslim.

Within Islam, the scared and the profane are integrated and not separate as deemed within both the modern and the postmodernist framework, which has separated it altogether. Al-Attas points out that the world itself does not change and develop but it is life that undergoes changes and thus it is life that need to be carefully looked after, for it is this that has implications in the hereafter. He develops a critique of secularism or post-modernistic view, which is defined as "the deliverance of man from religious then from metaphysical control over his reasons and his language" stating that it has been taken out of its original context and meaning of this concept, where it means the laity or the uneducated or the unlearned. However, with its evolution, it came to be represented as de-linking of religion and its symbols from all aspects of life, where the profane and the sacred are totally different.

Secularisation, one of the key features of both modernism and post-modern relativism has been conceptualized as a mental evolutionary process, whereby man comes of age, developing from a childish state to one that is seen as a mature one, with the development of the consciousness of man away from myths and superstition. This is where man becomes responsible and accountable for his actions and destiny. This argument fails when one examines history and witnesses the major contributions made by the great India, Chinese and Islamic civilisations, which has 
invariably contributed to building the foundations of modernity be it in the field of both natural and the social sciences.

It is argued by al-Attas that focusing on worldly ends does not pose and issue in Islam and it is also not exclusive of the spiritual aspects, where both this world-dunya and the next world the akira are inter-linked and cannot be separated. On the other hand, even though secularism is opposed to religion and its ideology, it is an ideology itself, with its own biases and conditionalities.

In terms of the concept of happiness, which is seen as one of the central goals of human life from many perspectives, Ibn Sina conceived it as be gained through the intellect grasping the eternal objects, which perfects the human soul. A Muslim perspective is that eternity is achieved through gaining knowledge and agrees with Ibn Sina's view that 'knowledge is perfection and perfection is happiness ${ }^{32}$.

The Aristotelian view of happiness is akin to the modern concept, with it directed to this world only, with the difference being that that the virtue or the moral code guides the Aristotelian, as compared to the modern or post-modern concept. This differs from the concept in Islam, which related to happiness being rooted in this world and has its link to the next world. This is epitomized in the oft repeated prayer "O our Sustainer! Grant us good in this world and good in the life to come....."33

\section{Conclusion}

The shift in paradigm has occurred, where things having objective reality as in modernism to reality being socially constructed, with language being the medium of discourse and the instrument of control in post-modernistic relativism. This thinking which has been translated into secularism is impacting the Muslim world through its educational system and multi-media.

Islam has both the rational and the non-rational perspective and in this sense is holistic in its nature with its focus on the continuum of dunya-akira. Thus, there is direction and meaning, where things can be explained within the life in this world, as well as the next, while touching on perennial issues such as suffering,

\footnotetext{
32 Inati, "Epistemology in Islamic Philosophy."

${ }^{33}$ Al-Qur'an, al-Baqarah, 2:201.
} 
death, injustice, dignity, oppression - all of which are contentious, without a proper frame of reference especially for those having a purely materialistic ideology, whereby Islam provides both the material, as well as the spiritual framework as a means of guidance.

The treat from post-modernism is pervasive given the penetration of the western world on other cultures and societies and it does pose a challenge to Islam especially for the young minds that is trying to come to grips with its own tradition. Notwithstanding this, the threat within certain sections from within Islam seems more direct and real given the lack of understanding or misunderstanding the Islamic epistemology. Within both these strands of thought and ideology, the challenge, however, for Islam is first, in relation to the Muslim masses being properly educated pertaining to understanding the substantive knowledge content and its pathway of enlightenment embedded in the Qur'an, Sunnah and within Islamic epistemology. Second, in Muslims themselves accepting the principles and differences, within their communities, with tolerance for others perspective given that Islam is not monolithic, as well as building an integrated system of education and its dissemination through the multiple media that is now pervasive. In conclusion, it is to be noted that the Islamic Civilization would not have unraveled itself, if not for its approach of universality and being open to critical analysis and filtering of thoughts from other traditions set within the Islamic framework.

\section{Bibliography}

Al-Taftazani, Sa'd al-Din, On the Creed of Najm al-Din al-Nasafi: A Commentary on the Creed of Islam, translated with introduction and notes by Earl Adgar Elder, edited by Austin P. Evans (Columbia University Press, New York, 1950).

Bukhari,; "Dealing with People and Good Character (al-Adab alMufrad al-Bukhari)," translated by Aisha Bewley, Sunni Path: On-Line Islamic Academy, http://www.sunnipath.com/library/Hadith/H0003P0014.aspx, accessed on $7^{\text {th }}$ January 2014.

Duigan, Brian, Postmodernism (philosophy), Britannica Online Encyclopedia, 
www.Britannica.com?EBchecked/topic/107729/postmodernism -and-relativisim, accessed on 21 November 2013.

Gruber, T.R., "What is Ontology," last modified 1992, http://www-ksl.stanford.edu/kst/what-is-an-ontology.html, accessed $5^{\text {th }}$ January 2014.

Habermas, J. in Wilfred Carr and Stephen Kemmis, Becoming Critical: Education, Knowledge and Action Research (The Falmer Press, London, 1986).

Inati, Shams, "Epistemology in Islamic Philosophy", 1998, 2-3; $\mathrm{http} / \mathrm{muslim}$ philosophy.com/ip/rep/HO19; accessed on $2^{\text {nd }}$ December 2013.

Matthias, Steup, "Epistemology", The Stanford Encyclopedia of Philosophy (Winter 2013 Edition), Edward N. Zalta (ed.), http://plato.stanford.edu/archives/win2013/entries/epistemology $/$, accessed $4^{\text {th }}$ December 2013.

May, Tim, Issues, Methods and Processes (Open University Press, 1997).

Merriam Webster Dictionary, http://www.merriamwebster.com/dictionary/ontology, accessed on December 2013.

Munsoor, Mohamed Safiullah, "A Qualitative Assessment of Successful Local Organisations (LOs): A Critical Study of Northern Rakhine State (NRS), Myanmar" (Ph.D thesis, University of Reading, UK, 2003).

Rosenthal, Franz, Knowledge Triumphant: The Concept of Knowledge in Medieval Islam (Leiden: Brill, 2007).

The Dalai Lama, The Four Noble Truths of Buddhism: Fundamentals of the Buddhist Teachings, translated by Geshe Thupten Jinps, edited by Dominique Side (Harper Collin Publishers, new Delhi, 1997). 
Munsoor, Post-Modern Relativist Challenges on Islamic Epistemology 